\title{
Uma evolução subterrânea: \\ o jornalismo de Patrícia Galvão
}

Kenneth David Jackson ${ }^{1}$

\section{Resumo}

O jornalismo de Patrícia Galvão, uma produção vasta que abrange trinta anos tumultuados (1931-61), oferece ao leitor um retrato de época de uma jovem inteligente consciente das falhas, mas também das possibilidades culturais e políticas de um país em fase de modernização. Essa produção de Pagu revela uma escritora poderosa, além dos romances, com um conhecimento profundo, e muitas vezes pessoal, de escritores e artistas, comunicado em centenas de comentários e de resenhas críticas. Por meio do jornalismo constante, Patrícia nos permite acompanhar vivamente o percurso de uma vida inteira.

\section{Palavras-chave}

Pagu, jornalismo, crítica, sociedade, literatura, teatro, depoimento.

I Kenneth David Jackson é professor de Literatura Luso-brasileira em Yale. Entre seus livros estão Haroldo de Campos: A Dialogue with the Brazilian Concrete Poet (2005), A vanguarda literária no Brasil (1998) e Adverse Genres in Fernando Pessoa (2010). 


\title{
An Undercover Evolution: The Journalism of Patrícia Galvão
}

\author{
Kenneth David Jackson
}

\begin{abstract}
The journalism of Patrícia Galvão - a vast output that spans thirty turbulent years (1931-61) -, offers the reader a portrait of the time of an intelligent youth, aware of the flaws and the cultural and political possibilities of a nation in the throes of modernization. It reveals a powerful writer beyond her comfort zone of the novel, possessed of a deep and very often personal knowledge of authors and artists, registered in hundreds of comments and critical reviews. Through her consistent journalism, Patrícia helped us accompany a whole lifetime with particular vivacity.
\end{abstract}

Keywords

Pagu, journalism, criticism, society, literature, theater, chronicle. 


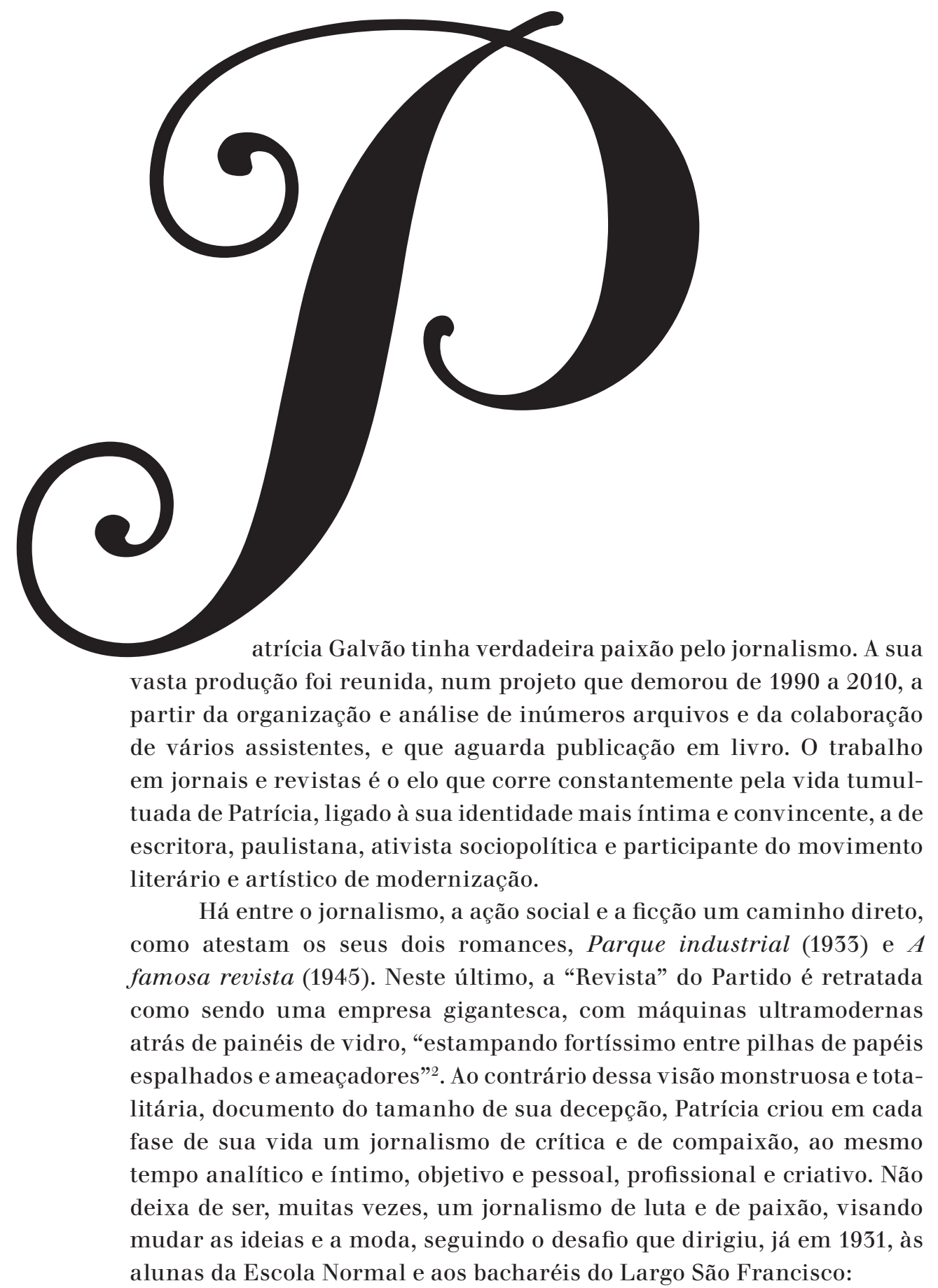

2 A mulher do povo, in O homem do povo. Rio de Janeiro: José Olympio, 1959, p. 17. 


\section{3/04/31 "Normalinhas"3}

Vocês também não querem que nem os seus coleguinhas de Direito, trocar bofetões comigo?

O que caracteriza o seu jornalismo é uma participação ativa na vida paulistana, e, mais tarde, santista, além da capacidade de expressar ideias e sentimentos em prosa sucinta e sintética, baseada em observações ou experiências pessoais. Patrícia escreveu centenas de colunas durante trinta anos (1931-1961), formando inevitavelmente o retrato de um período de grandes mudanças na vida pessoal e nacional, na política, no pensamento e nas artes e letras. Por meio do jornalismo, foi criando um panorama que começa com o movimento modernista e se estende até à democracia e às novas vanguardas dos anos 1950. É um jornalismo de ideias, que debate e dramatiza a luta diária dos paulistanos, enquanto contribui para o enriquecimento da vida cultural, literária e artística nacional. Desde centenas de colunas, fala com uma voz sempre pessoal e autêntica.

Em que consiste o jornalismo de Patrícia Galvão? Aos 18 anos, participa na Revista de Antropofagia, em 1928, com desenhos das aventuras da heróina "kabeluda", criadora de um jornal que fechou. Em 1931, já com o nome de "Pagu" - alcunha inventada por Raul Bopp - publica oito colunas de "A mulher do povo", na revista $O$ homem do povo, com Oswald de Andrade, conhecidas por meio da edição fac-símile de Augusto de Campos (1984). No Rio de Janeiro, como proletária a serviço do Partido, publica colunas no Diário de notícias (1933). Depois de sair da prisão, onde ficou detida de 1936 a 1940, volta ao jornalismo. Escreve 111 colunas assinadas “ARIEL" na revista $A$ noite, de 22/08/42 até 31/12/42. De 31/08/45 a 9/8/46, publica extensos comentários sobre a inteligência, política e poesia brasileiras, em 26 colunas na Vanguarda socialista, de Mário Pedrosa. Nesse período, em parceria com o crítico de arte Geraldo Ferraz, com quem se casou em 1940, começa a série "Antologia da literatura estrangeira", no Diário de S. Paulo (24/11/46 até 28/11/48), dedicada a autores da literatura mundial, com mais de noventa nomes, apresentados e traduzidos por Patrícia. Continua a retratar autores mundiais no jornal A Tribuna, de Santos, com números especiais, dedicados a Sigmund Freud, Heinrich Heine e Rainer Maria Rilke, entre outros. Vai publicar, de 1955 a 1961, sete crônicas sobre Fernando Pessoa, que contam entre os primeiros trabalhos no Brasil sobre o consagrado poeta da vanguarda portuguesa.

3 Fontes dos textos aqui apresentados: O Arquivo do Estado de São Paulo; A Tribuna (Santos); Arquivo Edgard Leuenroth; Biblioteca Nacional, Rio de Janeiro; Benson Latin American Collection, University of Texas at Austin. 
Em 1946, começa uma longa série de colunas assinadas "Pt.", sob a rubrica "Cor local" (24/11/1946 a 28/11/1948). Escreve também cerca de 87 títulos, com continuação no Jornal de São Paulo, com onze colunas (1949). Em 1954, produz dezesseis artigos para o jornal $A$ Tribuna de Santos. Ainda na década de 1950, publica na revista Fanfulla - muitas vezes a única coluna em português numa revista de língua italiana duas séries: "Duas faces do mesmo dia", sendo cinquenta colunas sobre diplomacia internacional e a guerra da Coreia (16/07 a 17/09/50), seguida da série "De arte e literatura", com setenta crônicas que tratam de artistas, escritores e obras brasileiros (15/10/50 a 21/6/53).

Em 1955, dá início à série "Palcos \& atores", no suplemento literário d'A Tribuna (Santos), onde publica 159 colunas sobre teatro, a grande paixão da fase santista, entre 3/7/55 a 2/10/55 e 7/01/57 a 1961. Continua o trabalho de crítica literária nacional, comentando a literatura brasileira em duas centenas de artigos na série "Literatura", assinada como "MARA LOBO", sempre em letras maiúsculas, o velho pseudônimo do romance Parque industrial, de 1933. O seu último esforço é uma série de colunas sobre televisão, "Viu, viu, viu?", publicadas de 5/10/61 a 23/9/62, quando já se encontra gravemente doente.

Portanto, a trajetória jornalística de Patrícia é muito rica, começando na adolescência e se estendendo até o penúltimo mês de vida. Mas por que Patrícia Galvão resolveu dedicar-se ao jornalismo e qual a sua orientação? Em três colunas, de 1942, apresenta-se aos leitores e explica a razão dessa escolha:

\section{1/10/42 "Resposta"}

Respondo a meu paciente leitor, a meu ilógico leitor, que tolera a leitura de minhas sandices, que também sou um mísero mortal. Gosto muito de meu churrasco e de minhas batatas fritas e se sonho com azuis e com alturas é porque desconheço estas distâncias e ignoro o caminho para lá. Se o meu amigo não sonha é lastimável porque ficará apenas com o bife e as batatas.

Em todo o caso, como não passo de um vendeiro de crônicas, estou aqui para servir os fregueses e se me pedem coisas insossas trataremos de achá-las.

Andei buscando a sociedade. Segui ruas estranhas, franqueei salões estranhos, de casas estranhas. Não encontrei nada. O maior salão da minha peregrinação estava vazio. Cheguei coberto de poeira do caminho, cansado, aflito, esfomeado, mas nada encontrei. Não consegui matar a minha fome nem minha sede. Num último esforço 
procurei falar e as paredes riram porque ninguém respondia. Ninguém poderia me responder, pois não havia ninguém.

Andei pelos bairros, pelos bares e cabarés. Ninguém estava no meu caminho. Havia ruídos estranhos, trombetas sonoras e sapos na paisagem. Mas nenhum indício humano. Onde estaria a sociedade? Onde estaria a vida humana para meus assuntos sociais? Depois de muito caminhar folguei encontrar uma roda de alegria. Risos, ruídos, palavras sem nexo. Fôra apenas, porém, ilusão de meus sentidos, miragem à insatisfação do viajar.

Estava já desesperançado e miserável, quando a última estrada me surgiu para o último convite. Grandes ramos e muita fertilidade abriam o caminho. Arvoredos fechados denunciaram a sua fertilidade. E vislumbrei as habitações da estrada com os sintomas da vida que procurava. Moravam ali a criança e o poeta.

Ela percebe no jornalismo "a eventualidade de novos vôos" e "a promessa do real conhecimento das coisas e do mundo". Insiste em incluir nas reportagens o sonho e a poesia, junto às agudas percepções e às emoções:

\section{2/08/42 "Primeira Página"}

A expressão "crônica social" da rotineira terminologia jornalística, pode ter hoje uma significação transcendente. Há sempre a eventualidade de novos vôos.

\section{9/08/42 "Adolescentes"}

Haverá entre as inutilidades deste século, tempo útil para o real conhecimento das coisas e do mundo, tão alardeado pelos defensores do progresso calamitoso e inconseqüente pelos que não conhecem os prismas das palavras, confundidos por falsas e superficiais visões?

Por que ler o jornalismo da Patrícia Galvão e qual o seu significado nos dias atuais? Nessa vasta produção, encontra-se uma voz única e forte, de uma mulher envolvida apaixonadamente nas correntes históricas de sua época. Paralelo ao livro Viva Pagu: fotobiografia de Patrícia Galvão, de Lúcia Maria Teixeira Furlani e Geraldo Galvão Ferraz (São Paulo/Santos: Imprensa Oficial do Estado de São Paulo/Editora da Unisanta, 2010), que desenvolve as muitas fases contrastantes de sua vida por meio de imagens, o jornalismo igualmente segue o fio cronológico do seu desenvolvimento intelectual e dá voz às múltiplas fases de sua vida. Acompanha seus 
interesses e suas paixões e, ao retratar a condição sociopolítica nacional, nos revela os seus conceitos íntimos e as suas mudanças de visão. Trata-se, possivelmente, de uma versão feminina e mais extensa de uma "Crônica da vida que passa", como Fernando Pessoa publicou na imprensa lisboeta, ou notas de desassossego, dado o vazio do encontro de Patrícia com a sociedade. Nesse sentido, o jornalismo é biografia, mas também documento e registro. Traça um retrato da vida brasileira em vasto panorama, constituindo um painel das grandes mudanças e apresentando muitos dos temas mais importantes do século XX, passando do modernismo, às ideologias políticas, ao ambiente da Segunda Guerra Mundial e a volta à democracia. Ao mesmo tempo, é a biografia intelectual de uma jovem paulistana.

Desde as primeiras colunas, Patrícia dirige uma crítica avassaladora aos vícios e às vicissitudes da vida social, da economia, da política e dos valores da sociedade brasileira. Escreve constantemente, dedicadamente. E mostra-se uma grande crítica de literatura e estética, com uma produção maior do que aquela sobre política. Podemos afirmar que suas colunas equivalem não apenas a um "diário crítico", comparação que ela mesma levanta com o amigo Sérgio Milliet, mas também às memórias de um Pedro Nava, ou ao Jornal de crítica, de Álvaro Lins, e a outras obras panorâmicas de época. Entretanto, o jornalismo de Patrícia, tão abrangente e variado como os diários críticos, é mais empenhado na relação entre a autora e seus temas diversos. Mais do que jornalismo, assemelha-se a uma ficção objetiva e a uma observação romanesca. Em sua totalidade, é uma crítica de paixão e de poesia que Patrícia nos deixou.

Para um conhecimento mais profundo do jornalismo, que percorreu quatro décadas, no que diz respeito aos grandes temas da biografia de Patrícia, será necessário um passeio por entre as mais expressivas colunas do seu jornalismo. Dessa maneira, será possível perceber os grandes temas e a expressividade íntima, a voz inconfundível da autora-jornalista, observadora culta, crítica incessante e participante apaixonada na vida brasileira.

\section{São Paulo antigo}

Talvez por causa do seu conhecido papel de figura chave no movimento modernista, cuja voz progressiva apoiava a mudança de valores, não se pensa em Patrícia como filha de habitantes de um São Paulo de imigrantes do fim do século XIX, com uma rica memória da cidade. Na coluna "Legendas", ela descreve um ambiente de outros tempos, faz uma evocação de São Paulo antigo: 
26/09/48 "Legenda"

Era bom São Paulo antigo. Era romântico São Paulo antigo. Todo o mundo se amava. Tinha campos e campinas e bosques por toda a parte. E havia grades em torno do jardim da minha Escola. E dentro das grades, uns enormes olhos melancólicos orlados de preto sob pestanas rimeladas e que não pegavam incêndio embora dentro das pupilas um puro fogareiro ardesse sempre vivo. Sempre vivia a saudade destes lampiões. Chegava uma mulher; encostava num lampião. Chegava um homem, tirava uma linha comprida, ou uma corda. Dava uns passos pra lá do lampião. Voltava para debaixo da luz. Via os olhos com as pestanas em risco de pegar fogo. Falava umas coisas. Sentia-se importante, da altura de um vulcão; aquela estava arrumada. Não se sabe de onde, a moça do lampião tirava uma tábua e lascava no atrevido. Essas eram cenas de grand-guignol que a cidade conhecia nos seus silentes - sim senhor, silentes - crepúsculos, ou, melhor, noitinha. Bondes pervagavam dentro das ruas da minha cidade, o homem que acendia lampiões cumprimentava a rua inteira do meu bairro. Era noite fechada já. A moça no lampião. Romântica e divagante. E havia árvores repolhudas que sombreavam tudo. Repolhos, roxos de saudade. E neste instante preciso apenas uma papoula vermelha sobre um disco negro. Que nem num quadro de Calder. Ou que nem duas imagens superpostas que vou religando por estas ruas de hoje, densas de misérias esparsas pelos apartamentos da desgraça, pela fome e a morte que soluçam atrás de tantas portas. Namoros da cidade de outrora, tão romântica cidade, todos se amavam, tantos se amavam, ia-se pela rua a mão na mão...

Observa os hábitos urbanos das paulistanas com olho certo e satírico, característico do seu jornalismo posterior:

10/09/42 "Carta de Solange"

Outro dia, passando pelo Viaduto do Chá, vi uma de nossas senhorinhas, filha de tradicional família do luxo paulistano, apresentando uma dessas pavorosas misturas que só o mau gosto costuma revelar.

O fundo era de uma destas nossas últimas manhãs frias e cinzentas de inverno. E partindo deste fundo a senhorinha se envolvia num pesado "Cavour" cor de ferrugem. Mas seria necessário que lhe cortássemos a cabeça e os pés para ser admirada esta magnífica criação de célebre costureiro. É que da silhueta bem talhada duas longas e bonitas pernas desnudadas 
terminavam em sandalinhas estivais, e a cabeça, a pobre cabeça friorenta, conduzia no alto da arquitetura capilar, que já era uma afronta para a manhã um primoroso amontoado de palhas e rendas copiadas fielmente, de uma "vamp", figurando num filme ambientado na mais tórrida região do mundo.

Em 1933, publica uma cena que parece pertencer ao romance Parque industrial, tanto pela temática da pobreza, como pelas citações tiradas diretamente da fala do povo. O trecho enfatiza a origem popular do romance, ligado à reportagem:

1933 "Habitação coletiva” (Diário de Notícias, Rio)

Um preta deformada aparece com o filho cinzentinho. Uma teta escorrega da boquinha fraca, murcha sem leite. $\mathrm{O}$ avental encarvoado enxuga os olhinhos remelentos.

- Gente pobre não pode nem ser mãe! Me veio esse filho nem sei como. Tenho de dar pra alguém pro coitado não morrer de fome. Se eu ficar tratando dele, como é que arranjo emprego? Tenho de largar dele para ficar tomando conta dos filhos dos outros. Vou nanar os filhos dos ricos, e o meu fica aí sem num sei como.

\section{Patrícia modernista}

Embora adolescente, Patrícia Galvão participou no modernismo paulista como testemunha e estudante. Foi aluna de duas grandes figuras da época, Mário de Andrade e Tarsila do Amaral. No jornalismo, chegou a fazer um retrato insólito retrospectivo do "professor feio de riso de criança grande”:

\section{3/02/47 "Depois de amanhã Mário de Andrade"}

Mário de Andrade tinha um riso largo de criança, na minha infância, ou roubando frutas no tabuleiro da casa que tinha perto do Conservatório, na avenida de São João, e nós meninas sem saber que aquele professor comprido e feio de riso de criança grande, era um poeta, comia amendoim abrindo o clan de jaboti, e ninguém de nós no piano, na sala, na rua, na porta, pressentindo "depois de amanhã o porvir, sim, o porvir..." Nenhuma de nós sabia que o poeta era o poeta, que o professor fosse outra coisa. Um dia no circo, Piolim me contou que Mário professor era seu Mário, dono dos terrenos de Macunaíma. No 
circo que aprendi. "Quando era criança o circo de domingo divertia-me toda a semana. Hoje só me diverte o circo de domingo de toda a semana de minha infância". E depois de amanhã, continuo lhe recordando o perfil solitário de uma dedicação a saber coisas, outras vezes de querer fazer coisas tão grandonas que nem ninguém pode fazer até agora, e nós todas indiferentes diante do poeta que nos amava tanto, que até um dia, um dia o coração doeu muito, depois de amanhã, sim, depois de amanhã.

Na retrospectiva de 1950, Patrícia retrata a sua ex-professora de arte, Tarsila do Amaral, num depoimento comovente:

\section{0/12/50 "Tarsila do Amaral"}

Tarsila do Amaral vai nos devolver alguma coisa dos dias idos e vividos, em sua mostra retrospectiva.

Conheci Tarsila do Amaral nessa fase. Queria falar-vos dela, de sua pessoa mais profunda do que a moça de sociedade e brilhar em autenticidade nos salões de outrora... Tarsila é antes de tudo uma personalidade.

Uma personalidade de escola, quase de fora, não fora a sua inclusão na rotina da produção rural, como beneficiária das fazendas paternas, como proprietária depois - essa mulher superou um padrão alto demais para o meio. Ela me parece ser o nosso primeiro caso de emancipação mental entre as mulheres paulistas e não por uma questão de riqueza, de formação intelectual, ou de viagem. Sacudida nas alturas de uma pretensiosa "high life" ou deixada no quadro modesto de um atelier de pintura, o sonho nas mãos. Tarsila do Amaral manteve o seu sorriso bom e acolhedor, a sua compreensão superior, a sua inteligência sempre aberta à pesquisa, e com tudo isto uma dose de infinita modéstia, de esquivança nobre, nunca deixando de ser a primeira, mas fazendo tudo por que não o percebessem... Esta delicadeza iria mais longe ainda no desejo de não ferir suscetibilidades.

Interessante que há em Tarsila também ao lado da tessitura cubista em que repousam certas das suas melhores soluções, um realismo ingênuo a Rousseau, o douanier. O senso decorativo dela se irmana bem com certas folhagens de Rousseau, certas flores, certos bichos desse pintor desprevenido. Aos que estejam informados, a cronista deve aproximar a idéia que guiava Rousseau e que o aproxima de Tarsila. Rousseau tinha em conta certas paisagens mexicanas. A nossa paulista redescobre em adulta a paisagem dos seus olhos de menina, depois de pintora formada. Sua melhor pintura, a mais caracterizada, 
sairá desse redescobrimento em si mesma. Uma otimista filosofia da vida tramada numa consciência nítida de um ambiente, com os cafusos, os santinhos, os olhos grandes de gente mestiça, produtos de oratório e de festas de julho, aguais, relvas, cactus, eis Tarsila.

Ela adquiriu um misticismo original na fase da antropofagia, ainda dentro de seu colorido regional. A descoberta do social, entretanto, devia-lhe ser de uma fatalidade esgotante. A pintora voltou a sua atenção para a cidade, e não foi tão feliz, embora sua sinceridade não tenha que será que discutida.

Não sei por que vicissitudes Tarsila não continuou a ser a grande pintora que vinha sendo entre 1925 e 1930. Não lhe adiantou nada à sensibilidade a sua viagem à Rússia. Aliás, que é que podia mesmo adiantar? Ela como artista colocara-se marginalmente à camada social a que pertencia. Isto sem jamais deixar de ser individualizada, na sua criação e no seu esforço. A descoberta do social tendo produzido alguns quadros destroçadores de sua visão da vida, Tarsila retorna ao nível anterior da pintura gratuita. Não encontrei, entretanto, nela, nenhuma das descobertas mais de outrora...

Personalidade, porém, continuou a mesma. A deformação de sua passagem pelo social não lhe quebrou o senso profundo de equilíbrio, a sábia penetração psicológica, a serenidade de julgamento e compreensão. A mesma “emancipação mental” permanece a dirigir-lhe os passos, com a mesma segurança de sempre.

Hoje, que Tarsila organiza a sua exposição retrospectiva, uma história a se incorporar a todo o plano de nossa pintura moderna, o que foram os seus esforços por uma série de afirmações virão a tona, num meio completamente diverso daquele em que se produziram, sem os estímulo do sonho e da luta, numa barulhenta e aturdida cidade, perdida para o ideal e para a pesquisa... Não sei como vamos ter aqui a retrospectiva de Tarsila. Não sei que peças virão, não posso imaginar se será uma grande exposição ou apenas uma histórica demonstração da pintura de Tarsila.

Cabe saudá-la, entretanto, na medida em que nos devolver a glória luminosa de seus dias idos e vividos, a flexibilidade harmoniosa com que a moça paulista retratou, em simplicidade e coragem, um panorama, um ambiente, uma gente, de um instante transitório.

Embora limitada pela tenra idade, Patrícia seguiu os debates da Semana, até poder entrar no movimento com participação na Revista de Antropofagia e o próprio romance, Parque industrial, atualmente reconhecido como texto clássico do modernismo paulistano. Duas décadas 
mais tarde, documenta a sua crescente consciência do modernismo em formação, à base do que "outros viram":

03/12/50 "Um debate que promete"

... O debate entre modernismo e academismo começou em S. Paulo com o cubismo... Foi um desenho, um carvão cubista de Anita Malfatti que fez Monteiro Lobato se descobrir como grande crítico de pintura. Ele jamais passou de Almeida Júnior, em pintura, e Anita Malfatti foi-lhe um golpe no queixo. Antes de Anita, passara pela província, mais quieta, sem dúvida, do que hoje - porque então minha infância se lembra do remanso - antes de Anita, chegara por aqui Lasar Segall.

Foi Segall o primeiro expressionista que vimos. Que viram, retifico, porque eu não vi. Outros viram, sim.

Segall expôs em Campinas. Com acuidade demais para a cegueira em que vivia a então Princesa d'Oeste, um crítico local chamou o pintor de "pintor de almas". Não acham acuidade? Por que, o que era o expressionismo senão a busca do que está dentro da carne, dos ossos, atrás dos olhos espavoridos de seus modelos? E Segall ficou "pintor de almas". Ninguém suspeitou que era o expressionismo que botava a raiz no chão de São Paulo. O escândalo despencou por cima de Anita Malfatti. Sei que Anita, muito sensível, angélica, sofreu com o ataque brutal. Não esperava, estava longe de perceber que o cubismo fosse tão chocante... Quem mandava ela andar pelos Estados Unidos, pela Europa, recolhendo a informação das vanguardas?

Seguiu-se a Semana de Arte Moderna. Seguiu-se o escândalo dessa brilhante semana, o rompimento de Graça Aranha com a Academia Brasileira de Letras, surgiu o "Pathé Baby" de Antônio de Alcântara Machado e "Macunaíma" de Mário de Andrade, herói sem nenhum caráter entrou no cordão, e chegamos nós, um dia, com a Antropofagia. Tudo isto dava discussão. Escrevi, então, "pour épater" também o meu romance social, o primeiro desta cidade e se chamou "Parque Industrial". Tudo isto é história. Entrementes, conhecemos, depois da pintura de Anita e da escultura de Brecheret, da pintura de Tarsila e da música de Villa-Lobos, da literatura de "pau-brasil", de antropófagos, de extremismos, a nossa arquitetura moderna, com uma exposição que houve numa casa racional do Pacaembú... História a ser contada um dia de repente a cidade amansou, quietou-se, não quis saber de mais nada. 
Espírito jovem, Patrícia vive o estado de "bagunça transcendente", invenção do modernismo poético, mostrando desde cedo uma simpatia pelo mimo ou ator que, desafiando os códigos vigentes, ensina outro caminho de pensamento e de comportamento, exemplificado aqui pelo amigo, Flávio de Carvalho:

\section{8/09/42 "Mixigne"}

O nosso amigo Flávio de Carvalho deu-nos a chave de tal gregueria. "O mixigne é um homem que se equilibra no ar, desobediente à gravitação, ao dicionário, que consegue esmagar a relatividade das coisas e dominar todas as perspectivas de uma só vez. É o que nos deixa com as palavras quando a nossa vaidade procura convencer, é o que sorri quando há tristeza, e troca os sapatos com o primeiro defunto. O mixigne conversa apenas com o candidato suicida, lê jornais velhos e livros que não existem. Apanha flores nos jardins suspensos das lendas e conta histórias às crianças. E no meio das luzes de uma cidade nascente, desconhecendo o trânsito, os apitos, as buzinas, posta-se no meio do trilho para falar às estrelas.”

Já em 1946, Patrícia é capaz de fazer um balanço do movimento, julgado em comparação ao "espírito do século vinte", que conhece na pesquisa estética e linguagem de poetas da vanguarda europeia. Com uma visão cultural internacional cosmopolita, é capaz de ver nos poetas "canibalmente nacionalistas" uma virtude, mas também uma limitação, se não fundados na pesquisa e na leitura:

04/01/46 "Linha do determinismo histórico literário do Ano Novo" A definição da literatura brasileira que espero para o ano que entra se concilia bem ao drama colonial em que vive o Brasil. Desde menina ouvi falarem, na minha cidade, da literatura moderna... Na tranqüila capital da província, com a garoa e as cotações do café, um grupo de literatos e artistas, muito reduzido, produzia escândalos com a literatura moderna. Nobres jornais, de venerados títulos e revistas, acolhiam a colaboração de Osvaldo de Andrade, Alcântara Machado, Mário de Andrade, Rubens Borba de Morais, Sergio Milliet. De todos, o que teve parada na província, para não mencionar o seu oposto, o parisiense-londrino Paulo Prado, Mário de Andrade foi o que fez a independência de sua concepção literária apenas pelos livros. O mais eram brasileiros itinerantes, gente que tinha semanalmente saudades da Europa. Eles conheceram a literatura moderna pelo contato com a civilização ocidental, e a sua reação 
na Semana de Arte Moderna, na Poesia Pau-Brasil, no "Pathé-Baby" de Antônio, talvez se tenha feito nacionalista por se sentirem ainda coloniais perante a Europa. Acrescentaram porém à literatura brasileira o que nunca mais lhe seria acrescentado até agora: o espírito do século vinte. Embora canibalmente nacionalistas, a pesquisa e a preocupação lingüísticas de Mário de Andrade são a melhor prova, foram modernos. Apollinaire, Max Jacob, Cocteau, Aragon, Breton, etc. (e não faço distinção entre esses nomes por que os estou citando historicamente como dados de influência e sem lhes considerar a evolução posterior, as dissensões e divergências), eram poetas de cabeceira da geração paulista que fez literatura moderna no Brasil. SÓ UMA OUTRA REVOLUÇÃO ARTÍSTICA PODE SUBSTITUIR NA HISTÓRIA E EVOLUÇÃO DA NOSSA SENSIBILIDADE E DA NOSSA INTELIGÊNCIA A REVOLUÇÃO DE 1922.

\section{Memórias do cárcere}

Em 23 de janeiro de 1936, Patrícia foi presa e indiciada pelo Tribunal de Segurança Nacional por "crime contra a segurança política e social”. Conseguiu escapar em 25/20/37, mas foi novamente detida em 22/4/38 e transferida para a prisão comum de mulheres da Casa de detenção, em 22/10/39, onde permaneceu até 9/6/40. Em colunas subsequentes à sua soltura, escreve sobre os anos de prisão, o cansaço e o desespero que sentiu durantes esses anos:

07/12/47 "Monograma da véspera"

Desgraçadamente ponto. É como se eu estivesse na Casa de Detenção e esta carta tivesse de passar pelo crivo da censura do sr. Diretor dos forçados. Então tinha de medir os gemidos das ondas destas grades. (A vela se abrira naquela manhã, depois de tanto tempo, tanto tempo, a vela branca vagara pela fímbria delgada no horizonte distante, desaparecera na luz, sumira na aurora e na noite, parecia gozar de plena liberdade lá longe quando desapareceu e que talvez não voltasse mais). Agora quero lhe dizer que espero a sua voz e que me ouça.

Começa, então, a formar por intermédio do jornalismo uma visão existencialista, cheia de desengano para com os idealismos e as adesões da juventude: 
04/04/48 "Conclusão lógica desses delírios”

A verdade é que vamos, inocentes, na solidão. Os que marchavam durante a jornada com os seus objetivos práticos atendem às solicitações do abismo. É um profundo e largo, amplo deserto. Amor furioso em gemidos esquematizados externamente. Aqui dentro não: arrastamos o imprevisto, as situações formam seus andaimes, caímos dentro do sapato, passamos sob a rocha, um gigante bambeia segurando as pedras, colocamo-nos fora da porta, no corredor que leva, aonde?

Escreve uma carta ao filho de quem foi separada por longos anos. $\mathrm{Na}$ imagem de um barco sem cais, comunica a solidão e a futilidade da separação da criatura que criou e ama:

30/11/47 Não tenha medo do escuro (carta ao filho Rudá)

Quereria lhe escrever Rudá nestas linhas a minha carta de amor da noite em que estamos perdidamente clandestinos no barco imenso que bóia sobre as águas do mundo tomado de dilúvio. Rios correm pelos sulcos de todos os países, bichinhos humanos pequeninos sem mãos adultas puxando seus passos infantes, e nós com a obrigação de amar-nos por nós e por todos nesta enseada onde bóia o grande barco agora chegado a nenhum cais. Não é lamento nem sofrimento - é apenas a constatação. Sei que me vês assim mesmo na noite. Cheguei com as mãos cheias de cravos. Ouvirás apenas o rumor silencioso deste perfume que sobe das pétalas de joelhos aos seus pés meu pequenino.

Quereria lhe escrever esta carta de amor que não passará da noite noturna de nossas mãos unidas sobre estrelas mortas, vazios desertos espaços sem mundos estelares vácuo e silêncio embora apenas se percebam os ruídos do outro lado. Do outro lado da parede.

Numa coluna de "Cor local", comenta a viagem à China, de 1935, onde começa a conhecer os esquecidos e torturados do grande mundo, seja qual for a ideologia dominante:

\section{2/12/42 "Sábado em Cantão"}

Não foi muito difícil ver o gado morto através das grossas fibras tecidas. Fios de sangue escorriam das manchas salientes para empapar as vestes de seus portadores.

Uma mulher de negro, deformada, se esforçara para romper as amarras do gune, e quando o conseguiu despiu um cadáver. 
E todos os sacos se abriram despindo os mortos e os barcos gemeram. Eram homens mutilados, crianças sem pernas, troncos de mulheres. Alguns olhos escorriam como água... Os homens do rio seguiram as ilusões das montanhas onde o sonho reverberava, e desapareceram numa auréola de névoa.

De volta a um Brasil democrático, e depois de anos encarcerada, começa a questionar as possibilidades de uma democracia num mundo manipulado pela mídia, pela pobreza e pela exploração socioeconômica. Quer redefinir a função da cidadania, conceito que fundamenta o panfleto Verdade e Liberdade (1950), com que se candidata à Assembleia Legislativa do Estado de São Paulo, sem sucesso:

\section{2/11/47 "Liquidação geral"}

É impossível a um cidadão independente exercer o seu dever de eleitor e usufruir de seu direito de voto nesse polvilho que está sendo atirado aos sete ventos, e através de bocas escancaradas de gramofone, passando à minha porta que nem o verdureiro, o peixeiro, o laranjeiro, também o homem que vende sempre gordos frangos e vem a lenga-lenga de tantos partidos políticos e é uma beleza porque todos eles estão com o povo, a iniciativa aliás é comunista, contra a exploração, a miséria e outras bagatelas. Tudo etiquetado com iniciais que se transmutam em parcelas, somam, multiplicam, diminuem, dividem e acaba-se não mais se sabendo a quantas andam, e é por isso que agora cada um procura o seu, lesando a fila do ônibus, como se ama por aí, onde estás ó porto da esperança?

Por meio do jornalismo, domina a sátira dos costumes das ideias, desta vez dirigida com toda versatilidade linguística contra o populismo da campanha de Luís Carlos Prestes em 1945:

\section{1/09/45 "A konstituinte kremiliniana"}

Nada de eleições diretas em 2 de dezembro! O Dutra e o Eduardo ke se konformem! O kerido precisa kontinuar. De kualker maneira. O povo está kom êle e Karlos Prestes está kom o povo. Viva o Kerido! Viva o Keremismo! Viva Karlos Prestes! Viva a Konstituinte! Viva o Kremlin!

Até fins dos 1940, a sua voz equivale a uma consciência humanista e ética, dirigida a um mundo que, depois de Hiroshima e Nagasaki, se lança na era atômica com testes atmosféricos, conduzidos numa condição 
quase de ignorância e sem as mínimas precauções ante a elementos radioativos:

01/08/48 "Nós os bombardeados"

Fico pensando no milagre desta imagem. Esse velho navio que as experiências mortais levaram a Bikini e que depois ao largo de Havaí foi colocado sob a morte de várias outras armas secretas. Nem em Bikini nem agora o barco perdeu o equilíbrio sobre as ondas... Para que morrer? Para que iludir os soldados e os técnicos com a submissão vergonhosa ao seu poderio de destruição? Bombas atômicas, raios que o partissem, cacos de ferro derretido e rubros em fogo, apenas lascaram as madeiras, arranharam as traves, estremeceram as armações. Não, um navio não é feito para morrer, mas para viajar pelo mar, visitar os portos, deixar lenços brancos e andar carregado de saudades e transportando esperanças, reunindo risos nos portos e traduzindo palavras de todos os países, carregado de sonhos, de audácia e de elegância, impávido sob as tempestades, sereno nas grandes jornadas sobre o azul debaixo do azul, todo branco de luz... Por que há de um navio se prestar aos testes de morte? Recebe, ó NEVADA, a minha homenagem e o meu adeus agora que decidiram quebrar o símbolo de paz que pairava na figura inamolgável sobre a superfície líquida, o meu aplauso, o meu hurrah de alegria pela tua resistência admirável! A quilha se perderá agora quebrada pelos abusos do bárbaro ímpeto, mas que não puderam nada os meios modernos e técnicos de matança isso não puderam. Adeus, ó heráldico, hurrah, à fé que paira sobre essa vida atormentada, bombardeada como a minha, amen. - Pt.

\section{Crítica literária: "moderna mesmo deve ser dita"}

Patrícia dedicou centenas de crônicas à literatura nacional e estrangeira, a partir das colunas da Vanguarda Socialista, em que apoia a autonomia da literatura, a sua independência e soberania por sobre as paixões humanas. É uma das primeiras pessoas a ler e comentar a obra de Antonio Candido, cuja voz e obra vão lidar com a crítica brasileira na segunda metade do século XX:

28/09/45 "Pequeno prefácio a um manifesto" 
Reiniciando a crítica literária cotidiana, o intelectual paulista Antônio Candido, escreveu há dias no pórtico de suas tarefas: "Pretendo tratar a literatura cada vez mais literariamente, reivindicando a sua autonomia e a sua independência acima das paixões nem sempre límpidas do momento."... Trata-se na verdade de defender as obras literárias pelo que elas são e devem valer, aos olhos dos intelectuais que as cultivam. Porque, como observa Antônio Cândido, atravessamos uma situação de perigo para as letras, e essa perspectiva o leva a pensar "na obrigação que temos de prestigiá-las".

Volta a defender, como também defende Oswald de Andrade em ensaios de época, as conquistas e os significados do modernismo literário:

15/10/50 "Contornos e desvãos de um panorama sumário"

Reclamava ainda há pouco o mestre (jovem mestre) Antônio Cândido, no pequeno semanário dos socialistas, a falta hoje de uma "literatura moderna" no Brasil. Antônio Cândido é da geração dos que cresceram num tempo em que havia "literatos" modernos, o motivo suficiente de se acreditar então numa literatura moderna. A própria designação hoje é tida por suspeita. Pois não é. Moderna mesmo deve ser dita, para se entenderem as coisas na porção polêmica e pesquisadora que significam, quando se trata de uma literatura como a desejada.

Defende a escola nacional de literatura, não como subespécie, mas com a obrigação de construir a sua própria grandeza, sem se limitar a qualquer margem, mas colocada e lida necessariamente junto às obras da literatura mundial, como convém a uma sociedade moderna e cosmopolita:

\section{2/10/45 "Problemas da crítica"}

Vejamos agora a chamada escala nacional que coloquei atrás entre parênteses. De meu ponto-de-vista não temos grandes escritores. Costuma-se dizer, porém, de fulano ou cicrano: "Para o Brasil, contudo trata-se de um grande escritor". Ou estão: "Sua obra no Brasil, é já uma grande realização". E outras bobagens do mesmo quilate, incidindo num critério limitado pelo nosso atraso, acima e à margem da literatura mundial. Será esse o meio de conseguirmos uma linha alta de produção literária? Não estaremos pela 
crítica dentro dessa escala protetora, para não dizer patrioteira, cultivando as nossas anemias?

\section{A volta de $A$ escada}

Depois da morte de Oswald de Andrade, em 1954, Patrícia escreve uma coluna evocando o cenário do romance $A$ escada (1934), cuja realidade ela viveu quando casada com o escritor. Trata com alguma ironia $o$ suposto ambiente revolucionário daquele romance, acabado num exílio no litoral, na Ilha das Palmas. Depois de publicada essa coluna, volta inesperadamente à vida essa realidade perdida com a visita à repartição, em Santos, de vários dos personagens do romance, após um intervalo de vinte anos. Patrícia cria um título proustiano para uma segunda coluna, na qual descreve a volta a tempos passados, como se o contato com a ilha perdida no tempo ligasse magicamente alguns dos fios perdidos de sua vida. Na alegria e emoção do reencontro, ela sente e diz, talvez pela única vez, que valeu a pena ter vivido:

6/11/54 "Um romancista na Ilha das Flores" (sobre "A Escada" de Oswald de Andrade)

Um romancista só, não. Um romance, protagonistas, figuras de "estas", como se diz das fitas de cinema.

A morte de Oswald de Andrade faz reviver esse cenário da velha ilha, hoje turística e de clube, quando naquele tempo serviu apenas de refúgio ao herói de "A escada vermelha", transfiguração deformada da "A escada de Jacó", porque Oswald se tornara um extremista, como sempre fora, aliás mas, então, com pretensões a militante revolucionário, a "casaca de ferro" da Revolução Proletária... upa!

A ilha das Palmas de faro teve no romancista e no romance uma parte que, na versão primitiva, era grande, era mesmo a mais importante. Na versão publicada, reduziu-se a proporções de umas cinqüenta páginas ou pouco mais, e nelas se encontrara sempre o gosto amargo do mar batendo nas pedras... "Uma real impossibilidade de demarches fatalizava os olhos de Jorge diante do mar que o cercava. Aquela primeira semana acalmara-lhe as nervosas precipitações do instinto. Ante o oceano largo, as serras e a floresta do litoral, tinha uma sensação de eternidade imóvel. Para que correr, afligir-se, chorar? A vida naquele casto ermo, era isenta dos fervilhamentos das podridões. A própria fisiologia aproximava-o da 
animalidade dos pássaros da terra e do mar. Havia festas de velas brancas para os seus olhos nas manhãs estáticas. Uma fita de neblina anelava o recôncavo. A gente boa da ilha trabalhava calmamente. Seu Luiz, num gorro de marinheiro, varria as boas folhas tombadas nos caminhos de pedra, nos pontilhões, nas veredas terrosas. Uma proa de transatlântico, rumando para Santos, destacava-se vagarosamente do cabo abrupto dos morros".

20/11/54 "Em busca do tempo perdido"

$\mathrm{Na}$ crônica aqui publicada num destes dias sobre o romance "A Escada Vermelha", a propósito da morte de Oswald de Andrade, referi-me aos personagens e ao cenário, este que era o da Ilha das Palmas, aqueles que eram habitantes daquele recanto esplêndido de nossa paisagem.

A crônica foi lida por uma daquelas personagens. Veio esta de Vila S. Jorge, em São Vicente, à casa de dona Maria das Palmas, à avenida Senador Dantas, no Macuco. Alertou pedaços daquele bloco de personagens do romance, e um porta voz nos procurou.

Na tarde de ontem, após 23 anos de separação, reencontramos a septuagenária que faz, na "A Escada Vermelha”, as vezes de Dona Amélia.

Soubemos então dos verdadeiros destinos: d. Maria das Palmas ali estava, recordando-nos alguns de seus 14 filhos, falando-nos dos seus netos e até dos bisnetos. Vitória Agonia voltou a esse passado de menina onde o romancista a encontrou.

Que é que o leitor tem com isso?

O Leitor, ocasionalmente, poderá conhecer algumas dessas pessoas. Poderá não as conhecer. Isto significa, entretanto, de qualquer forma, um testemunho da vida, e quando a vida se prende à arte, como acontece neste caso, algo sobrevive ao anônimo cotidiano, a rotina dos destinos inexpressivos, na palpitação criadora de heroísmo, de corações, de uma coragem de viver que sobrepassa a estagnação da morte.

É a vida que flui, a arte que permanece, e entre o que passa, e o que fica, os homens traçam a sua grandeza e a sua dignidade. Falar desses personagens é evocar, nessa paisagem, num tempo intensamente vívido, as esperanças, a bondade, o amor, o esforço generoso que nunca buscou recompensa. São coisas pelas quais ainda valeu a pena ter vivido.

$M A R A L O B O$ 
Voltando a escrever sob o pseudônimo do primeiro romance, imposto pelo Partido, mas desta vez à guisa de ironia, e como manifesto de sobrevivência, Patrícia se coloca a serviço das letras, defensora e propagandista da necessidade da leitura para o bem-estar tanto da pessoa como da sociedade.

07/04/57 "Imprescindível a leitura"

Por que temos um rádio, uma televisão, e não temos uma estante de livros em casa?

A tarefa essencial de uma cidade que cultua a inteligência, de uma cidade que aspira a uma posição, é a de MANTER E CULTIVAR O GOSTO PELA LEITURA.

A serviço dessa diretriz colocamo-nos aqui, agora e sempre, pela leitura e para a leitura.

MARA LOBO

Revisita os grandes temas aos quais se dedicou com alma e corpo, com a energia e o entusiasmo da sua juventude, falando de todos os nãolugares de um submundo que chama e merece a nossa atenção humana:

26/09/42 "Algures"

Algures é um lugarzinho lúgubre onde ardem os céus e a terra, onde existem cheiros e destroços, onde moram, em casas soterradas e ruínas, a palidez, a fadiga, o entusiasmo, a vingança. $O$ céu de Algures é um céu de fogo e a terra está doente. Às vezes, um rio vermelho é cruzado por embarcações fantasmas, por barcos de mortos e feridos, com mulheres queimadas e crianças transformadas em carvão. Às vezes Algures é branco, frio e silencioso... De Algures, alguém telegrafa para o mundo pedindo atenção.

No fundo, Pagu, sempre ela mesma, não deixa de se dirigir aos leitores e cidadãos com uma autocrítica, acompanhada por uma sátira devastadora dirigida à cultura geral e aos colegas, e a um corpo social que entende talvez excessivamente bem.

23/03/47 "Miséria elevada ao quadrado"

Que estou fazendo aqui com a minha formidável inteligência? Miséria.

Que estão fazendo os outros com a sua formidável burrice?... 


\section{A última coluna: "sem saber para quando"}

Por meio do seu jornalismo, Patrícia Galvão incentivava as pessoas a lutarem para encontrar soluções pessoais e sociais, como na coluna “Lute!" (03/09/42).

Ouve, Lúcia. Quando lhe deixei ontem, pensei que felizmente não é só você que possui grandes olhos de desespero, que há outras jovens e outras mulheres e mesmo alguns homens à procura estéril de um ponto de apoio... Não perguntarei a você para onde vai. Mas, desejaria que não se detivesse no círculo fechado das contemporarizações ou não se vergasse ao natural colaboracionismo com o senso comum. Prefiro a guerreira. Desejaria ver sempre uns olhos enormes, imensamente tristes, acumulando todas as dores dos homens. E você prosseguindo a luta dos náufragos do alto mar.

Na última coluna que escreveu, “Apertar o cinto" (26/3/61), afirma: "Nós ficamos. E lutaremos. Este o nosso até logo, embora sem saber para quando".

Na memória pessoal, escrita em 1940, e publicada como Paixão Pagu, somente em 2005, uma "autobiografia precoce", o leitor acompanha as lutas de uma jovem intelectual à procura de um ideal digno de sua dedicação vitalícia. Nessa confissão íntima, narra sobretudo seu envolvimento com o modernismo literário paulistano e depois com a política trabalhista e revolucionária dos anos 1930, culminando na sua grande viagem de exílio ao redor do mundo. O jornalismo completa esse pano de fundo, como um álbum de retratos e de ideias que ilumina passo por passo não apenas os grandes temas e acontecimentos comunicados, mas, sobretudo, a visão estética da autora, os pequenos detalhes cotidianos e as personagens do dia a dia, escolhidos para nos sensibilizar, para que entendêssemos o próprio espírito íntimo da autora. E, com o tempo e centenas de colunas, com crítica e compaixão, foi acumulando as experiências de uma vida inteira, humana e comovente.

Até quando, ela pergunta, poderá ficar para lutar? E eu pergunto, será para agora, na esteira do centenário, celebrado em 2010, com os romances, o livro de memórias e a fotobiografia em mãos, e a coleção do jornalismo em livro a vir? 